\title{
АКТУАЛЬНІСТЬ ФОРМУВАННЯ ІНТЕГРАЛЬНИХ ЗНАНЬ ТА НАВИЧОК 3 ПАЛІАТИВНОЇ ДОПОМОГИ У МАЙБУТНІХ ЛІКАРІВ
}

\author{
О. З. Децик, Г. М. Ерстенюк, Ж. М. Золотарьова
}

ДВНЗ “Івано-Франківський національний медичний університет”

\section{RELEVANCE OF THE FORMATION OF INTEGRATED KNOWLEDGE AND SKILLS IN PALLIATIVE CARE IN THE FUTURE DOCTORS}

\author{
O. Z. Detsyk, H. M. Erstenyuk, Zh. M. Zolotaryova \\ SHEI "Ivano-Frankivsk National Medical University"
}

\begin{abstract}
У статті обгрунтовано підхід наскрізного навчання як найбільш раціональний і ефективний спосіб формування інтегральних знань та вмінь 3 питань паліативної та хоспісної допомоги на додипломному рівні і запропоновано відповідну навчальну програму.
\end{abstract}

The article substantiates approach through-learning as the most efficient and effective way of forming integrated knowledge and skills for palliative and hospice care at undergraduate level and offered appropriate training program.

Вступ. Наслідком негативних тенденцій сучасного популяційного здоров’я в Україні (постаріння населення, зростання тягаря невиліковних захворювань з тривалим хронічним перебігом серед всіх вікових груп, значне поширення ВІЛ-інфекції та туберкульозу тощо) стало те, що для більш як 500 тис. хворих у фінальному періоді життя необхідна паліативна та хоспісна допомога (ПХД). Такої допомоги також потребують близькі і родичі, оскільки поява невиліковно хворого часто стає причиною тяжкої психологічної травматизації всієї сім'ї, викликає соціальні та економічні розлади їі функціонування [1]. Тому спеціальні знання з ПХД стали вимогою часу для всіх медичних працівників і потребують їх вивчення, зокрема й на додипломному рівні [2].

Основна частина. Аналіз рекомендацій міжнародних організацій, вітчизняних нормативно-правових актів, навчальних планів, програм навчальних дисциплін для студентів BНМЗ III-IV рівнів акредитації, а також результати власних досліджень, зарубіжний і вітчизняний досвід засвідчили недостатню увагу до питань ПХД в існуючій системі вищої медичної освіти на додипломному рівні.

3 метою поліпшення підготовки майбутніх лікарів проведено оцінку двох альтернатив вивчення питань надання ПХД: 1) введення окремої нормативної навчальної дисципліни або 2) застосування наскрізного підходу до інтегрального формування цих знань та вмінь.

(ㄱ) О. З. Децик, Г. М. Ерстенюк, Ж. М. Золотарьова
Встановлено, що підготовка у межах окремої нормативної дисципліни (альтернатива 1) має ряд позитивних моментів:

- концентрування в умовах однієї навчальної дисципліни всіх питань ПХД;

- можливість формального контролю отриманих знань.

Однак, на наш погляд, недоліків значно більше, a саме:

- неможливість виділення навчальних годин, оскільки в існуючому Галузевому стандарті освіти такого предмета не передбачено, а положення наказів МОН України № 642 від 09.07.2009 р., № 259 від 29.03.2010 р. та МОЗ України № 539 від 08.07.2010 p. не передбачають перевищення нормативного терміну навчання та кількості годин; забрати години в інших існуючих навчальних дисциплін видається досить проблематичним;

- за умови виділення годин виникне необхідність створення окремих кафедр чи курсів, підготовки викладачів, матеріально-технічного та методичного забезпечення навчального процесу, що вимагатиме значних матеріальних затрат, неможливих у сьогоднішній скрутній економічній ситуації;

- складність у межах однієї навчальної дисципліни охоплення всього комплексу аспектів ПХД (тим більше, що годин навряд чи буде достатньо);

- таку інтегральну дисципліну бажано вивчати на шостому курсі, який і так перевантажений вивченням предметів, що виносяться на державну атестацію; 
- труднощі формування практичних навичок.

Аналізуючи другу альтернативу, встановлено цілий ряд переваг. Зокрема, наскрізний підхід до формування знань і вмінь:

- не вимагає додаткових затрат на організацію навчального процесу;

- запобігає перенавантаженню студентів, оскільки акцентує увагу на питаннях ПХД, які входять у перелік тем та питань предметів, що вже викладаються;

- базується на принципах горизонтальної та вертикальної інтеграції впродовж всіх курсів навчання, що відповідає міжнародним рекомендаціям, оскільки дає можливість охопити всі аспекти проблеми та сформувати цілісні інтегральні знання з питань ПХД, сприйняти ідею мультидисциплінарного підходу;

- якомога ранній початок, починаючи 3 перших курсів, залучення предметів гуманітарних, соціально-економічних, природничо-наукових циклів підготовки акцентує увагу на базових поняттях, психологічних, духовних, етичних та правових аспектах супроводу паліативного пацієнта;

- наскрізний підхід дозволяє використати можливості як мінімум двох практик для формування необхідних практичних навичок;

- не суперечить існуючим вітчизняним навчаль-

\section{Література}

1. Покращення міжвідомчої та міжсекторальної координації та співпраці у галузі паліативної та хоспісної допомоги / Ю. І. Губський, А. В. Царенко, О. О. Вольф [та ін.] // Матеріали Всеукраїнської науково-практичної конференції "Соціальна політика щодо невиліковно хворих", 15-16 березня 2012 р., м. Київ. -К. : Університет" "Україна", 2012. -С. 3-20.

2. Recommendations of the European Association for ним планам і програмам, у тому числі включає як нормативні, так і вибіркові дисципліни;

- мотивує студентів через кращу поінформованість до майбутньої професійної діяльності.

Серед недоліків можна виділити деяку складність формального контролю знань. Проте внесення відповідних питань для контролю у переліки дисциплін, що вивчаються, а також у державну атестацію випускників дозволить нівелювати цю проблему.

За результатами дослідження розроблено типову наскрізну навчальну програму з питань паліативної i хоспісної допомоги для додипломної підготовки студентів медичних факультетів ВНЗ III-IV рівнів акредитації за спеціальностями "Лікувальна справа" та "Педіатрія", доцільність впровадження якої схвалено рішенням наради МОЗ України з питань розроблення та затвердження навчальних програм підготовки лікарів та молодших медичних спеціалістів 3 питань надання паліативної допомоги від 27 листопада 2013 року.

Висновок. Встановлено, що найбільш раціональним і ефективним способом формування інтегральних знань та вмінь з питань ПХД на додипломному рівні $є$ підхід наскрізного навчання. Запропонована відповідна навчальна програма.

Palliative Care (EAPC) For the Development of Undergraduate Curricula in Palliative MedicineAt European Medical Schools: report of the EAPC Steering Group on Medical Education and Training in Palliative Care [Electronic resource] / Edition 2013. - Access mode: https://mail.rambler.ru/m/folder/INBOX/ 7271.2/download/id/EAPC_UndergraduateCurriculum Update2013.pdf 